\title{
Lahirnya Identitas Baru: Pergeseran Budaya melalui Interaksi pada Karyawan Difabel Samakta Guest House
}

\author{
El Chris Natalia
}

\author{
Universitas Katolik Indonesia Atma Jaya, Jl. Jend. Sudirman No.51, Jakarta \\ Tlp. (021) 5708967, Email: chris.natalia@atmajaya.ac.id
}

\begin{abstract}
Cultural change and the emergence of identity in the individual can occur through interaction. Culture in an organization can form a new identity in individuals. The aim of this research is to know about the cultural shift experienced by the diffable employees who are deaf at Samakta Guest House in forming a new identity within them. The literature review used in this research includes intercultural communication, organizational culture, self-concept, and identity. This research is using a qualitative descriptive analysis. In collecting data, the researcher used an in-depth interview with four informants, ND, DD, JF, and PL. The result shows that deaf employees who work at Samakta Guest House have a special culture and identity or characteristic in themselves. Organizational culture and the process of interaction make the deaf employees become more developed and find new figures in themselves. Diffable employees adapt to new cultures. In forming this new identity, the interaction process that plays an important role in them is the interaction with the owners of Samakta Guest House and other diffable employees who work there. The substance of this research recommends that the organization, especially for the owner and manager of Samakta Guest House should develop a diffable-concerned organization
\end{abstract}

Keywords: Intercultural Communication, Organizational Culture, Identity, Diffable Employee, Samakta Guest House

\begin{abstract}
Abstrak
Perubahan budaya dan munculnya identitas dalam diri individu dapat terjadi melalui interaksi. Budaya di sebuah organisasi dapat membentuk identitas baru dalam diri individu. Penelitian ini bertujuan untuk mengetahui pergeseran budaya yang dialami karyawan difabel Tuli yang bekerja di Samakta Guest House dalam membentuk identitas baru pada diri karyawan tersebut. Penelitian ini menggunakan landasan teori berupa komunikasi antarbudaya, budaya organisasi, konsep diri, dan identitas. Metode yang digunakan pada penelitian ini adalah kualitatif deskriptif. Pengumpulan data dilakukan dengan wawancara mendalam kepada empat narasumber, yaitu ND, DD, JF dan PL. Hasil penelitian menunjukkan bahwa karyawan difabel Tuli yang bekerja di Samakta Guest House memiliki budaya dan identitas tersendiri atau ciri khas dalam dirinya. Budaya organisasi dan proses interaksi membuat para karyawan difabel Tuli menjadi lebih berkembang dan menemukan sosok yang baru dalam dirinya masing-masing. Karyawan difabel melakukan adaptasi terhadap budaya yang baru. Pada pembentukan identitas yang baru tersebut, proses interaksi yang paling berperan penting dalam diri karyawan difabel Tuli adalah interaksi yang dilakukan dengan pemilik Samakta Guest House dan karyawan difabel lainnya yang bekerja di sana. Substansi penelitian ini memberikan rekomendasi kepada organisasi, khususnya pengelola Samakta Guest House untuk selalu menanamkan budaya organisasi peduli difabel.
\end{abstract}

Kata kunci: Komunikasi Antarbudaya, Budaya Organisasi, Identitas, Karyawan Difabel, Samakta Guest House

\section{Pendahuluan}

Budaya selalu melekat dalam diri seseorang dan menjadi bagian dari masyarakat. Budaya tidak hanya berbicara mengenai suku, agama, ras, tetapi juga mengenai nilai-nilai, karakter, kebiasaan dan kepercayaan yang dimiliki seseorang. Budaya itu sendiri bersifat dinamis di mana budaya yang dimiliki seorang individu dapat mengalami pergeseran atau perubahan. Sebagai contoh, seseorang yang memasuki sebuah lingkungan baru, tidak 
menutup kemungkinan orang tersebut akan mengalami dan mengikuti budaya baru yang terbentuk dari lingkungan tersebut. Setiap individu pasti memiliki budaya yang dapat mempengaruhi bagaimana berinteraksi dengan orang lain.

Menurut Triandis (Samovar et al., 2013:36), budaya adalah komponenkomponen objektif dan subjektif yang dibuat oleh manusia di masa lampau untuk bertahan hidup dan dibagikan atau diteruskan di antara anggota kelompok karena memiliki kesamaan bahasa dan tinggal di waktu dan tempat yang sama. Bicara mengenai budaya, tidak hanya mengenai hal-hal yang tampak dari luar, seperti warna kulit, suku, jenis kelamin, dan lainnya tetapi juga mengenai apa yang tidak terlihat, seperti kebiasaan atau nilai-nilai yang dianut oleh seseorang. Inilah yang dapat dikatakan budaya bersifat kompleks.

Budaya ada di berbagai konteks, salah satunya dalam sebuah organisasi. Setiap organisasi memilik karakter dan nilai-nilainya sendiri yang membedakannya dengan organisasi lainnya. Sebagai contoh, perusahaan W.L. Gore \& Associates, perusahaan yang menghasilkan pakaian-pakaian lapangan yang inovatif dan berkualitas tinggi. Perusahaan ini memberlakukan cara kerja tim melalui susunan organisasi yang fleksibel dan nonhierarkis bagi para karyawannya dalam mengembangkan produk-produk inovatif. Budaya yang ada pada perusahaan ini adalah budaya yang berorientasi pada manusia (Robbins dan Coulter, 2012:63). Pada contoh ini, budaya tersebut dikatakan sebagai budaya organisasi. Budaya dalam sebuah organisasi dianut oleh para anggota dalam organisasi dan ini dapat mempengaruhi bagaimana mereka bekerja dan berinteraksi dalam organisasi tersebut.

Budaya yang melekat dalam diri seseorang, kelompok atau organisasi dapat membentuk identitas. Identitas adalah konsep diri kita. Menurut Martin dan Nakayama (Samovar et al., 2013:206), identitas adalah mengenai siapa diri kita dan siapa kita menurut orang lain. Identitas bersifat dinamis. Setiap individu dapat memperoleh identitas baru sebagai sebuah proses hidup. Berdasarkan hal tersebut, maka dapat dikatakan bahwa setiap individu dapat memiliki lebih dari satu identitas pada dirinya (Samovar et al., 2013:206).

Identitas diri selalu melekat pada seseorang dimanapun orang tersebut berada. Seorang karyawan akan membawa identitas dirinya ketika berada di sebuah organisasi, namun tidak menutup kemungkinan akan munculnya identitas diri baru yang terbentuk dari organisasi tempat dirinya berada. Karyawan dapat menemukan adanya perbedaan budaya saat mulai bekerja di organisasi yang baru. Identitas awal yang ada dalam diri karyawan memungkinkan mengalami pergeseran identitas karena terbentuk dari budaya dalam organisasi tersebut. Pergeseran identitas tersebut bisa dilakukan melalui interaksi dengan para karyawan atau atasan yang ada di dalam organisasi tersebut. Bahkan tidak menutup kemungkinan identitas muncul karena adanya interaksi dengan publik eskternal dari organisasi.

Identitas dapat terbentuk dari berbagai proses dan mengalami perkembangan atau perubahan. Tujuan penelitian ini untuk melihat bagaimana identitas dalam diri seseorang dapat bergeser saat berhadapan dengan budaya 
organisasi yang baru. Terdapat tiga penelitian terdahulu yang menjadi rujukan mengenai pergeseran identitas. Penelitian pertama (Adyapradana, 2018:8) menyatakan bahwa identitas dapat bertumbuh dan berkembang pada media baru, yaitu online game. Penelitian tersebut berfokus pada identitas dan pembentukan stereotip daripemain online game Battle of Immortals (BoI). Hasil penelitian tersebut menunjukkan bahwa pemain pada game tersebut akan membawa idetintasnya masing-masing sebagai individu, namun bisa berkembang atau berubah seiring dengan fungsi dan pengalamannya dalam online game. Hasil analisis ditemukan bahwa pemain online game dari Indonesia menghadapi kesulitan untuk berbaur dengan pemain yang berasal dari negara lain dan cenderung mengidentifikasi perilaku seseorang berdasarkan identitas kelompok orang tersebut.

Penelitian kedua adalah penelitian yang dilakukan oleh Dewi dan Widyowati (Dewi et al., 2017:154). Penelitian berjudul "Pembentukan Identitas Budaya Remaja dari Keluarga Pernikahan Beda Budaya”. Penelitian tersebut menunjukkan bahwa proses pembentukan identitas dapat muncul melalui keluarga, teman dan lingkungan masyarakat. Garisketurunan tidak selalu berpengaruh dalam pemilihan atau pertimbangan suatu identitas budaya, tetapi yang dapat mempengaruhi adalah pilihan pribadi dan pengaruh pergaulan.

Penelitian ketiga adalah mengenai konstruksi identitas yang dilakukan oleh media massa lokal (P. A. R. Dewi, 2017:1567158). Penelitian tersebut melihat bagaimana pembangunan identitas yang dilakukan oleh media massa lokal terhadap tiga artis yang terlibat dalam video yang berisi adegan seksual. Hasil penelitian tersebut ditemukan bahwa media memiliki kekuatan dalam membangun identitas yang diberikan secara "paksa" pada ketiga artis tersebut. Artis tersebut tidak memiliki daya untuk melawan atau menolak apa yang dibentuk pada diri artis. Identitas melekat pada budaya karena tidak hanya dimiliki oleh individu-individu, tetapi juga dimiliki kelompok secara kolektif.

Dari ketiga penelitian tersebut dapat dikatakan bahwa identitas diri dapat berubah dan terbentuk melalui berbagai proses. Perbedaan pada penelitian ini dengan ketiga penelitian tersebut terletak pada topik penelitian. Penelitian ini melihat budaya organisasi dapat memberi pergeseran identitas dalam diri seseorang. Perbedaan budaya dan pengalaman dapat mengubah atau membentuk identitas diri individu. Budaya bersifat dinamis dan identitas tidak bersifat stagnan. Inilah mengapa budaya dalam diri seseorang bisa berubah ketika orang tersebut meninggalkan lingkungannya dan masuk ke lingkungan yang baru. Budaya yang bergeser ini mampu membentuk identitas baru dalam diri seseorang. Pembentukan identitas yang membuat seorang individu memaknai konsep dirinya berbeda dengan yang sebelumnya.

Terkait pembentukan identitas dan pergeseran budaya dalam sebuah organiasi, penelitian ini mengambil penelitian di sebuah penginapan. Dilansir dari blog resmi milik Kubca Samakta, Sumakta Guest House adalah sebuah penginapan yang berada di daerah Lembang, Bandung, Jawa Barat. Samakta Guest House merupakan salah satu unit dari sebuah organisasi yang bernama 
Kubca Samakta. Kubca Samakta merupakan sebuah organisasi sosial yang telah berdiri sejak tahun 1991. Pendiri organisasi ini adalah Nurmas Diana. Organisasi yang dibangun oleh Nurmas Diana ini berfokus pada kegiatan pengembangan diri dan kemandirian bagi remaja dewasa yang merupakan difabel. Samakta Guest House memiliki keunikan di mana yang akan melayani para pengunjung secara profesional adalah para remaja dewasa yang Tuli.

Majalah Kentingan Edisi September 2011 (Setyaningsih, 2016:43) menyebutkan bahwa sejak tahun 1999 istilah "penyandang cacat" berganti menjadi “difabel" (Different Ability). Penggantian istilah ini adalah untuk memberikan makna yang lebih halus serta lebih memanusiakan kaum berkebutuhan khusus. Penggunaan istilah difabel mengajak masyarakat untuk tidak memandang kondisi cacat atau tidak normal sebagai kekurangan atau ketidakmampuan. Istilah tersebut memberikan pandangan bahwa mereka yang difabel adalah manusia dengan kondisi fisik yang berbeda. Dilansir dari www.ilo.org, difabel seringkali dikucilkan secara sosial dan menghadapi diskriminasi dalam berbagai hal, seperti layanan kesehatan, pendidikan, dan pekerjaan. Sejalan dengan penghitungan WHO, diperkirakan 10 persen dari penduduk Indonesia (24 juta) adalah difabel. Jumlah difabel di Indonesia adalah 11.580.117 orang dengan di antaranya 3.474.035 (difabel penglihatan), 3.010 .830 (difabel fisik), 2.547.626 (difabel pendengaran), 1.389.614 (difabel mental) dan 1.158.012 (difabel kronis).

Menurut Nurmas Diana, Kubca Samakta didirikan secara spontan untuk memberikan peluang usaha atau kerja bagi orang-orang penyandang disabilitas. Misi organisasi Kubca Samakta adalah lembaga sosial yang menjembatani penyandang disabilitas untuk meraih prestasi dan kepribadian yang mandiri sedangkan visinya adalah mengutamakan prinsip disiplin, tanggung jawab, peduli terhadap sesama karena menjadikan SDM yang kompeten, aktif, kreatif, dan inovatif agar kedepannya berguna untuk diri sendiri dan sekitarnya. Sebelum mendirikan Kubca Samakta, Nurmas Diana juga telah lama berpartisipasi atau berada di lingkungan para penyandang disabilitas, khususnya di bidang pendidikan.

Kubca Samakta memiliki budaya organisasinya sendiri. Para karyawan difabel yang bekerja di Samakta Guest House menghadapi adanya lingkungan baru yang erat kaitannya dengan budaya baru. Budaya berkaitan erat dengan identitas, begitu juga sebaliknya. Identitas dapat muncul melalui berbagai interaksi yang dilakukan oleh karyawan dan budaya di dalam organisasi yang dihadapi para karyawan juga dapat membentuk identitas baru. Peneliti ingin memberikan gambaran bagaimana para karyawan di Samakta Guest House sebagai penyandang disabilitas memaknai budaya organisasi dalam membentuk identitas baru dalam dirinya melalui interaksi yang dilakukan dengan karyawan lainnya, atasan, atau bahkan pelanggan dari Sumakta Guest House. Penelitian ini menarik untuk diteliti dikarenakan budaya yang bersifat dinamis dapat membawa perubahan identitas seseorang.

Berdasarkan penjelasan di atas, maka rumusan masalah pada penelitian ini adalah 
"Bagaimana pergeseran budaya karyawan difabel Samakta Guest House dalam membentuk identitas baru melalui interaksi?". Tujuan penelitian ini adalah untuk mengetahui bagaimana pergeseran budaya yang dialami karyawan difabel Samakta Guest House membentuk identitas baru melalui interaksi. Penelitian ini berfokus pada bagaimana karyawan difabel yang bekerja di Samakta Guest House memaknai budaya organisasi dalam membentuk identitas baru karyawan melalui interaksi dengan pengelola, sesama karyawan dan pelanggan.

Penelitian ini berlandaskan beberapa teori. Pertama, Teori Komunikasi Antarbudaya, di mana komunikasi dan budaya saling mempengaruhi satu dengan yang lain. Komunikasi dapat menjadi sebuah cara dalam menciptakan dan menyebarkan budaya. Samovar et al. (2013:8) menyatakan bahwa komunikasi antar budaya terjadi saat anggota dari salah satu budaya menghasilkan pesan untuk dikonsumsi oleh anggota dari budaya lainnya. Berdasarkan pemahaman tersebut dapat dikatakan bahwa komunikasi antar budaya melibatkan interaksi di antara mereka yang memiliki kebudayaan, persepsi budaya dan simbol yang berbeda.

Kedua, Teori Budaya Organisasi. Budaya dalam sebuah organisasi menggambarkan karakteristik dan nilai-nilai yang dimiliki dalam sebuah organisasi. Kehidupan organisasi itu sendiri tercermin melalui budayanya. Robbins dan Coulter (2012:63) menjelaskan bahwa budaya organisasi adalah nilai, prinsip, tradisi, dan cara kerja di mana para anggota organisasi memahami, mengikuti dan membagikannya serta dapat mempengaruhi sebuah organisasi dalam beroperasi. Perkembangan zaman sangat berpengaruh terhadap bagaimana organisasi berjalan. Dalam hal ini dapat dilihat bahwa budaya merupakan persepsi di mana karyawan menerima dan memahaminya melalui pengalaman mereka di organisasi. Hal lainnya adalah budaya bersifat deskriptif; bagaimana para anggota organisasi menerima dan mengartikan budaya tersebut. Selain itu, para anggota organisasi yang memiliki latar belakang budaya yang berbeda cenderung mengartikan dan mengutarakan budaya organisasi dengan cara yang sama atau penerimaan bersama.

Teori yang ketiga adalah konsep diri. Menurut West dan Turner (2014:77), konsep diri berbicara mengenai perspektif yang dipercaya seseorang tentang dirinya sendiri. Black (DeVito 2016:76) menyatakan konsep diri terdiri dari perasaan dan pikiran seseorang mengenai kekuatan dan kelemahan, kemampuan dan keterbatasan, serta sudut pandang dari dirinya. DeVito (2016:76) mengatakan bahwa konsep diri berkembang dari: (1) gambaran/citra Anda yang dimiliki orang lain dan yang mereka ungkapkan kepada Anda, (2) perbandingan yang Anda buat antara diri Anda dan orang lain, (3) ajaran budaya Anda, dan (4) cara Anda menafsirkan dan mengevaluasi pikiran dan perilaku Anda sendiri.

Teori yang terakhir adalah identitas. Identitas berbicara mengenai konsep tentang siapa diri kita. Identitas selalu melekat dalam diri seseorang dan identitaslah yang menunjukkan siapa kita di hadapan orang lain. Ting-Toomey ( Samovar et al., 2013:206) mempertimbangkan identitas konsep diri atau 
gambaran diri direfleksikan oleh masingmasing individu yang diterimanya dari keluarga, gender, budaya, etnis, dan proses sosialisasi individu tersebut. Identitas muncul melalui interaksi-interaksi yang kita lakukan dengan orang lain. Identitas bermula dari pengaruh interaksi melalui pembentukan harapan dan motivasi perilaku (Hecht et al, dalam Samovar et al., 2013:219). Identitas berkembang dan bahkan dapat mengalami pergeseran ketika kita bertemu dengan orang lain dalam proses berinteraksi.

\section{Metode Penelitian}

Penelitian ini menggunakan metode analisis deskriptif kualitatif. Menurut Gall, Gall \& Borg (Nassaji, 2015:129), tujuan dari penelitian deskriptif adalah untuk mendeskripsikan sebuah fenomena dan karakteristiknya. Teknik pengumpulan data yang dilakukan pada penelitian ini adalah dengan melakukan wawancara mendalam. Menurut Croucher dan Cronn-Mills (2015:156), wawancara bertujuan untuk mengajukan pertanyaan dan mendapatkan jawaban dari narasumber atau informan yang berkaitandenganpenelitianuntukmendapatkan atau menggali informasi dan pengetahuan. Wawancara mendalam dilakukan terhadap pendiri, pemilik sekaligus pengelola Kubca Samakta, yaitu ND; asisten pengelola Kubca Samakta, DD; dan dua orang karyawan difabel yang bekerja di Samakta Guest House, yaitu JF (33) yang telah bekerja selama 18 bulan dan PL (19) yang telah bekerja selama 11 bulan. Wawancara mendalam dilakukan di Samakta Guest House, Jl. Hortikultura Lembang No.1, Jayagiri, Lembang, Kabupaten Bandung Barat, Jawa Barat. Pada penelitian ini dilakukan triangulasi sumber untuk keabsahan data. Peneliti melakukan pengecekan keabsahan data pada hasil wawancara yang dilakukan terhadap karyawan difabel dengan hasil wawancara dari pendiri serta asisten pengelola Samakta Guest House.

Subjek pada penelitian ini adalah ND, DD, JF, dan PL. JF dan PL merupakan karyawan difabel yang bekerja di Samakta Guest House, sedangkan ND dan DD adalah nondifabel. Kedua karyawan difabel ini adalah Tuli. Saat mencari data dengan melakukan wawancara terhadap dua karyawan Tuli tersebut, peneliti melakukan wawancara tertulis, yaitu dengan menggunakan alat bantu laptop. Teknis analisis data dilakukan dengan mereduksi data yang diperlukan untuk penelitian, menyajikan data untuk dianalisis dengan menggunakan teori atau konsep yang sesuai pada penelitian, dan melakukan verifikasi melalui triangulasi, kemudian menarik kesimpulan.

Saat menjawab pertanyaan tertulis, karyawan tersebut juga dibantu oleh pengelola dan asisten pengelola Samakta Guest House. ND dan DD membantu peneliti dalam memperjelas jawaban karyawan Tuli tersebut agar lebih jelas. Dikarenakan hanya menggunakan wawancara tertulis, maka hasil wawancara tidak bisa didapat dengan sangat mendalam. Wawancara dengan ND (sebagai pemilik) dan DD (asisten pengelola) dilakukan secara lisan dibantu dengan alat perekam.

Terkait data sekunder mengenai Kubca Samakta atau Samakta Guest House itu sendiri, peneliti sulit menemukan data dari website resmi Kubca Samakta sehingga ada data yang diambil dari blog resmi Kubca Samakta. Hal ini juga didukung pernyataan dari pendiri 
Kubca Samakta bahwa Kubca Samakta belum mempunyai website resmi.

\section{Hasil Penelitian dan Pembahasan}

\section{Budaya dan Komunikasi pada Karyawan Di- fabel Samakta Guest House}

Budaya dan komunikasi saling berkaitan. Setiap anggota budaya dalam melakukan komunikasi membagikan informasi dengan menggunakan simbol yang hanya dipahami oleh anggota budaya masing-masing. Simbol yang diberikan pun memiliki makna. Hubungan antara budaya dan komunikasi adalah kompleks. Budaya dapat mengalami perubahan berdasarkan komunikasi yang dilakukan dalam tiap konteks komunikasi.

Sebagai difabel Tuli, JF dan PL bersekolah di sekolah khusus, namun berbeda lokasi. JF bersekolah di daerah Bandung, sedangkan PL bersekolah di Yogyakarta. Berdasarkan hasil wawancara dengan ND, beliau menjelaskan bahwa cara mengajar di sekolah berkebutuhan khusus di Bandung dan di Yogyakarta berbeda. Di Bandung, murid difabel Tuli lebih sering menggunakan bahasa isyarat, sedangkan di Yogyakarta murid lebih sering diajarkan untuk menggunakan atau membaca gerak bibir. Apa yang dipelajari oleh JF dan PL ini menjadi sebuah budaya yang terus dilakukan dimanapun JF dan PL berada. Penggunaan simbol atau cara yang dipelajari JF dan PL hanya dimengerti oleh anggota budayanya masing-masing. JF tentunya sangat paham dengan penggunaan bahasa isyarat dan tidak lihai dalam membaca gerak bibir, sedangkan PL sebaliknya. PL sangat paham dengan membaca gerak bibir, namun tidak lihai dalam menggunakan bahasa isyarat. Berdasarkan hasil wawancara dengan JF dan PL, ketika ada komunikasi antara JF dan PL, terkadang ada hal-hal yang tidak bisa dimengerti walaupun mereka sama-sama Tuli. Cara berkomunikasi lainnya yang lebih membantu JF dan PL dalam berinteraksi adalah melalui Short Message Services (SMS) dan aplikasi chatting, seperti WhatsApp.

Menurut Samovar et al. (2013:41-54), karakteristik dari budaya adalah budaya dipelajari, diturunkan dari generasi ke generasi, berdasarkan pada simbol, bersifat dinamis, dan sebuah sistem yang terintegrasi. Budaya yang baru dipelajari ketika JF dan PL bekerja di Samakta Guest House. Keduanya menemui budaya baru yang membuat JF dan PL harus beradaptasi dengan budaya tersebut. Bagi JF, JF merasa nyaman ketika harus beradaptasi dengan budaya baru. Hal ini dikarenakan JF bertemu dengan teman-teman (karyawan) lainnya yang juga Tuli. Berbeda dengan PL, pada awalnya PL kesulitan berkomunikasi dengan teman-temannya yang bekerja di sana, namun PL pun terbiasa dengan penggunaan bahasa isyarat saat berkomunikasi dengan rekan-rekan kerjanya. Mempelajari budaya yang baru tersebut membuat JF dan PL mengalami pergeseran budaya. Inilah yang dinamakan budaya bersifat dinamis.

Komunikasi yang dilakukan antara ND dan DD dengan para karyawan Tuli di Samakta Guest House (termasuk JF dan PL) adalah dengan menggunakan bahasa isyarat dan ditambah dengan gerakan bibir, begitu juga sebaliknya. Budaya dalam berkomunikasi yang tercipta dalam diri JF dan PL juga diterapkan ketika bekerja di Samakta Guest House. Menurut ND, dirinya harus beradaptasi juga dengan 
cara komunikasi JF dan PL (dan bahkan karyawan difabel lainnya) untuk bisa memperlancar komunikasi antara dirinya dengan mereka. Jika berbicara dengan JF, ND akan lebih sering menggunakan bahasa isyarat sedangkan saat berkomunikasi dengan PL, ND akan berbicara dengan pelan (menegaskan ucapannya melalui gerak bibir) dan juga dibantu dengan bahasa isyarat. ND bahkan menuturkan dan mengajarkan pada peneliti, untuk berkomunikasi dengan orang seperti PL yang mengandalkan gerak bibir, disarankan bagi komunikator untuk tidak membelakangi matahari atau cahaya. Hal ini dikarenakan agar PL atau orang seperti PL bisa membaca gerak bibir kita dengan jelas tanpa harus terhalang atau silau karena menghadap matahari.

DD melakukan hal yang sama untuk bisa berkomunikasi dengan JF dan PL. DD, sebagai asisten ND, masih terbilang baru untuk bisa berkomunikasi dengan penyandang Tuli. Hal ini yang membuat DD pun mengakui masih belajar berkomunikasi dengan karyawan difabel di Samakta Guest House. Kesulitan yang biasa ditemui DD saat awal bekerja di Samakta Guest House adalah pada waktu memberikan briefing mengenai kegiatan apa saja yang harus dilakukan oleh para karyawan. Biasanya kegiatan yang dilakukan adalah membersihkan dan merapikan kamar, membersihkan taman, dan hal lainnya. Menurut PL, dirinya merasa sangat terbantu ketika ada briefing untuk mempersiapkan kamar yang dilakukan secara visual. Penuturan PL tersebut juga didukung oleh JF yang lebih mudah untuk belajar sesuatu secara visual dikarenakan keterbatasan komunikasi lisan.

\section{Budaya Organisasi di Samakta Guest House}

Budaya merupakan suatu hal yang diturunkan dari generasi ke generasi. Pada sebuah organisasi, budaya menjadi salah satu hal penting yang dapat dijadikan pegangan atau pedoman bagi para anggota yang berada di organisasi tersebut. Sebagai sebuah organisasi, Kubca Samakta memiliki beberapa lingkup usaha kecil di dalamnya. Salah satunya adalah Samakta Guest House. Berdasarkan hasil wawancara dengan ND, budaya yang ada di Samakta Guest House merupakan budaya yang sama yang ada di Kubca Samakta. Prinsip yang selalu ditekankan oleh ND dari sejak Kubca Samakta berdiri adalah peduli terhadap sesama, prinsipnya kekeluargaan, kerja keras, jujur, dan saling mendukung satu sama lain. Hal ini juga mengarah pada organisasi Kubca Samakta yang merupakan lembaga sosial.

Menurut Robbins dan Coulter (2012:66), sumber pertama budaya organisasi biasanya adalah visi para pendiri organisasi. Visi dan misi yang ada di Kubca Samakta juga menjadi pedoman dalam melaksanakan kegiatan dan mencapai tujuan organisasi. Menurut ND, misi Kubca Samakta adalah sebuah organisasi atau lembaga sosial yang menjembatani penyandang difabel untuk meraih prestasi dan kepribadian yang mandiri. Sedangkan untuk visinya, Kubca Samakta mengutamakan prinsip disiplin, tanggung jawab, peduli terhadap sesama dengan tujuan untuk menjadikan sumber daya manusia yang kompeten, aktif, kreatif, dan inovatif agar ke depannya berguna untuk diri sendiri dan sekitarnya.

Menegakkan atau menerapkan budaya organisasi dapat dilakukan dengan cara 
mengomunikasikan gagasan pendiri mengenai apa yang sangat sesuai kepada penerusnya atau karyawannya. Gagasan tersebut akan lebih mudah ditanamkan di dalam benak para anggota organisasinya jika organisasi berukuran kecil (Robbins dan Coulter, 2012:66-67). Lebih jauh, Robbins dan Coulter (2012:67) juga menjelaskan bahwa karyawan dapat beradaptasi dengan budaya organisasi melalui sosialisasi. Sosialisasi atau pengenalan adalah sebuah proses yang membantu para karyawan untuk memahami cara-cara organisasi menjalankan berbagai pekerjaan. Hal seperti inilah yang dilakukan oleh ND dalam mengajarkan budaya organisasi yang ada di Kubca Samakta pada karyawannya. ND menggunakan berbagai cara yang diterapkan di berbagai kegiatan secara langsung. Beliau selalu melakukan pendekatan dan memahami karakter individu. Kegiatan yang diberikan pada penyandang difabel yang ada di organisasi tersebut dikhususkan dengan bakat dan kemampuan mereka. Akan tetapi, ND tidak pernah membatasi untuk memberikan pelatihan-pelatihan di divisi-divisi yang lain. Melalui kegiatan tersebut, disisipkan atau diajarkan budaya yang ada di Kubca Samakta.

Karyawan yang ada di Samakta Guest House mempelajari budaya organisasi melalui berbagai hal. ND selalu melakukan "ritual" khusus dalam menyemangati dan menumbuhkan rasa percaya diri karyawan difabel di Samakta Guest House. Hal yang dilakukan adalah dengan mengapresiasi apapun yang dikerjakan para karyawan dengan mengancungkan jari jempol dan mengatakan "Hebat, kamu hebat!". Sebuah ritual yang sederhana namun berhasil menebarkan semangat dan percaya diri bagi karyawan difabel di sana dan budaya tersebut masih dilakukan hingga sekarang.

Penggunaan bahasa di Samakta Guest House cukup unik. Bahasa yang digunakan bukan hanya bahasa verbal, melainkan bahasa nonverbal. Bahasa nonverbal yang dimaksudkan di sini adalah penggunaan bahasa isyarat yang lebih sering menggunakan gerakan tangan atau jari dan ditambah dengan bantuan visual. Visual yang dimaksudkan di sini adalah memperagakan apa yang harus dilakukan. Selain itu, yang membuat organisasi ini unik adalah pihak pengelola dan pendiri Samakta Guest House dapat menerima perbedaan dari karyawannya difabel dan mempelajari dan menggunakan bahasa penyandang Tuli. Selain itu, untuk berkomunikasi dengan pelanggannya, bahasa yang lebih sering digunakan adalah bahasa lisan. Oleh karena itulah, saat berinteraksi dengan pelanggan, DD sebagai asisten pengelolalah yang mengambil alih. Menurut Robbins dan Coulter (2012:6970), bahasa memiliki peran sebagai sebuah identitas bersama untuk mengikat dan menyatukan para anggota organisasi. Sebagai sebuah identitas bersama di dalam organisasi tersebut, bahasa isyarat sebagai bahasa yang lebih sering digunakan dibandingkan bahasa lisan, dipelajari oleh anggota organisasi untuk mempermudah komunikasi antarmereka. Menurut DD, DD belajar bahasa isyarat dan beradaptasi sendiri dengan kondisi di Samakta Guest House untuk dapat berkomunikasi dengan karyawan difabel di sana.

Robbins dan Coulter (2012:64) mengatakan terdapat 7 (tujuh) dimensi budaya organisasi, yaitu perhatian pada 
detail, orientasi hasil, orientasi manusia, orientasi tim, agresivitas, stabilitas, serta inovasi dan pengambilan resiko. Dimensi budaya organisasi yang ada di Samakta Guest House adalah orientasi manusia dan inovasi serta pengambilan resiko. Dalam mengambil keputusan, pendiri dan pengelola Samakta Guest House memperhatikan karyawannya dalam bekerja. Berdasarkan hasil wawancara dengan ND, budaya kekeluargaan sangat ditekankan di Samakta Guest House, bahkan dijadikan sebagai bagian sentral dari budayanya. Menurutnya, budaya yang berorientasi pada manusia yang menekankan kekeluargaan ini membuat para karyawannya merasa nyaman berada di organisasi, lebih jauh lagi budaya kekeluargaan ini menular hingga ke para pelanggannya. Setiap orang memiliki kepribadian yang unik dan sudah seharusnya diperlakukan dengan baik sebagai keluarga di dalam organisasi tersebut.

Pada dimensi inovasi dan pengambilan resiko, dimensi ini menekankan pada seberapa besar organisasi mendorong para karyawannya untuk bersikap inovatif dan berani mengambil resiko. Berdasarkan hasil wawancara dengan ND, beliau mengatakan bahwa para karyawan yang ada di Samakta Guest House memiliki motivasi yang tinggi untuk melakukan inovasi dan mengambil resiko. Hal ini didukung dengan dedikasi tinggi, kemauan belajar yang luar biasa dan kemandirian dan ketrampilan karyawan yang sangat bagus. ND juga menurunkan budaya untuk berani mengambil resiko pada karyawannya. Sebagai contoh, ND menceritakan perjuangannya dalam mendirikan Samakta Guest House yang tidak mudah dan tak tentu. Menurutnya, pengambilan resiko dapat memberikan hasil yang memuaskan walaupun tidak bisa ditempuh dengan mudah dan dalam waktu singkat. Beliau menuturkan karyawan di Samakta Guest House diberikan pelatihan dalam membuat keramik. Suatu ketika, salah seorang karyawan berinisiatif meminta setengah kilo tanah liat. Tanpa diminta, ternyata tanah liat tersebut digunakannya untuk membuat keramik berbentuk kura-kura. Kreativitas karyawan tersebut pun akhirnya ditiru oleh karyawan lainnya yang membuat berbagai bentuk keramik. Keramik-keramik ini pun akhirnya dipajang di Samakta Guest House dan bahkan dijual kepada konsumen.

Selain itu, untuk mendorong timbulnya inovasi, ND seringkali mengadakan berbagai pelatihan bagi para karyawannya melalui kerja sama dengan berbagai asosiasi atau institusi pendidikan/pemerintah. Bahkan, takjarang ND juga membuka kesempatan bagi penyandang difabel lainnya yang ingin mengikuti pelatihan. Pelatihan lebih sering dilakukan di Samakta Guest House, namun tidak menutup kemungkinan diadakan di luar organisasi. Menurut ND, karyawan difabel yang bekerja di Samakta Guest House adalah orang-orang yang terampil dan mau berkembang dengan banyak belajar.

\section{Lahirnya Identitas Baru Melalui Interaksi}

Identitas dapat mempengaruhi peran sosial individu dan bagaimana individu tersebut berinteraksi dengan yang lainnya. Identitas, menurut Ting-Toomey (dalam Samovar et al., 2013:206) adalah konsep diri reflektif atau citra diri yang kita masing-masing berasal dari keluarga kita, jenis kelamin, budaya, etnis dan proses sosialisasi individu. Pada penelitian 
terdahulu, Ardyapadana (2018) menyatakan bahwa para pemain online game (sebagai informan penelitian) mengalami pekembangan identitas melalui interaksi dan pengalaman yang terjadi dengan pemain online game lainnya saat bermain.

Pada penelitian ini, dalam diri JF dan PL terjadi pergeseran identitas. Menurut JF, sebelum bergabung di Samakta Guest House, JF memandang dirinya sebagai individu yang tidak aktif, sedangkan menurut PL, dirinya adalah individu yang semangat, mempunyai keinginan untuk belajar dan sosok yang berani. Saat bekerja di Samakta Guest House, JF yang telah bekerja selama 18 bulan merasakan ada perubahan dalam dirinya. JF lebih sering bertemu dengan berbagai jenis orang yang membuatnya menjadi sosok yang lebih aktif dan bertanggung jawab. Menurut PL, selama 11 bulan bekerja di Samakta Guest House, PL lebih merasa mandiri, bertanggung jawab dan selalu merasa ada kesempatan untuk mengembangkan diri lebih baik.

Menghadapi pelanggan yang menginap di Samakta Guest House memberikan berbagai pengalaman bagi JF dan PL sebagai karyawan difabel. Cara berinteraksi yang dilakukan JF dan PL tentu berbeda dibandingkan ketika mereka berinteraksi antar sesama karyawan. Menurut PL, dirinya berinteraksi dengan pelanggan menggunakan bahasa bibir (gerakan bibir) dan sesekali dibantu dengan isyarat atau gerakan visual. Kesulitan yang dialaminya saat berinteraksi dengan pelanggan adalah pelanggan sering berbicara dengan cepat. Ini menyulitkan PL karena PL harus menyesuaikan diri dan membaca gerak bibir dari si pelanggan, sedangkan JF lebih sering menggunakan bahasa isyarat.

Berdasarkan hasil wawancara dengan JF dan PL, yang juga dikonfirmasi oleh ND dan DD, kebanyakan pelanggan yang menginap di Samakta Guest House tidak mengetahui bahwa JF dan PL tidak bisa berkomunikasi dengan lancar dikarenakan mereka adalah Tuli. Ada pelanggan yang pernah memanggil JF dan PL, namun keduanya tidak menoleh atau menjawab. Ketika pelanggan menanyakan hal tersebut ke DD, barulah pelanggan mengetahui bahwa JF dan PL adalah Tuli. DD pun akhirnya mengambil alih untuk mengurus keperluan pelanggan. Interaksi yang sering terjadi pada JF dan PL adalah komunikasi nonverbal, yaitu memberikan senyum dan salam. Salam yang biasa dilakukan oleh JF dan PL adalah dengan sedikit membungkukkan badan dan meletakkan tangan kanannya di pundak kiri seraya tersenyum.

Pergeseran identitas dalam diri seseorang bisa terjadi melalui refleksi dari orang lain, pengalaman, atau proses sosialisasi individu. Berdasarkan hasil wawancara dengan JF dan PL, keduanya menuturkan hal yang sama, yaitu sejak bekerja di Samakta Guest House, JF dan PL mengalami perubahan diri. Perubahan diri ini membawa perubahan juga pada identitas JF dan PL. Perubahan identitas yang terjadi pada JF adalah JF menjadi sosok yang disiplin, rajin, semangat, dan mau belajar. Perubahan diri ini JF dapatkan dari pengalaman dan sosialisasi atau interaksi saat dirinya bekerja di Samakta Guest House. Lingkungan dan budaya disiplin dan melakukan segala sesuatu dengan mandiri menjadikan JF sosok yang berbeda, sedangkan menurut PL, setelah bergabung di Samakta Guest House PL menjadi sosok yang lebih 
percaya diri, rajin, disiplin dan mau bekerja keras. Kebiasaan yang ada di Samakta Guest House membentuk dirinya dan menggeser identitas atau konsep diri yang selama ini ada dalam dirinya. Melihat dari apa yang terjadi di Samakta dan juga dari apa yang diajarkan dan dilakukan oleh ND dan DD, bahwa setiap orang yang bekerja di sana harus bisa hidup mandiri dan mau belajar, maka JF dan PL pun membiasakan diri dengan kebiasaan yang berlaku di Samakta.

Berdasarkan asumsi dari LaRossam da Reitzes (dalam West dan Turner, 2014:77-78), konsep diri tidak diperoleh seseorang dari lahir, tetapi belajar tentang diri dan memperoleh konsep diri dari interaksi. Penelitian terdahulu mengenai identitas terkait konsep diri, yaitu penelitian tesis Jhalugilang (2012:101-102) yang menunjukkan bahwa pembentukan identitas merupakan pencarian kejelasan dan pengintegrasian diri menjadi manusia secara utuh. Pada penelitian ini juga ditemukan bahwa para informan, yaitu fans Juventus (Juventini) mengalami pembentukan identitas melalui keluarga, teman, masyarakat, dan lingkungan sosial. Identitas sosial dalam diri seorang individu dapat membentuk konsep diri dan membuat individu tersebut berada pada suatu posisi tertentu.

JF dan PL menggunakan bahasa isyarat ketika berinteraksi dengan pelanggan. Menurut PL, selain menggunakan bahasa isyarat, PL juga membaca gerak bibir dari pelanggan. Berinteraksi dengan pelanggan membuat JF dan PL mendapatkan berbagai pengalaman dan mereka belajar dari pengalaman tersebut. Pada JF dan PL, mereka tidak terlalu sering berinteraksi dengan pelanggan dikarenakan mereka adalah penyandang Tuli. Biasanya, ND dan DD akan turun tangan ketika ada komunikasi mendalam yang tidak bisa dilakukan oleh JF dan PL, misalnya ketika pelanggan menanyakan mengenai fasilitasfasilitas di dalam kamar yang perlu dijelaskan dengan detail. Konsep diri yang ada dalam diri JF dan PL banyak terbentuk saat berinteraksi dengan ND, DD dan rekan-rekan kerja di Samakta Guest House. Salah satu hal yang membentuk diri JF dan PL melalui interaksi adalah kedisiplinan. ND dan DD selalu rajin memberitahukan dan mengajarkan hal-hal yang perlu dilakukan di Samakta Guest House. Walaupun ada kesalahpahaman, ND dan DD tetap sabar mengajarkan dan memberikan contoh secara visual agar lebih mudah dipahami oleh karyawan yang bekerja di sana. ND mengatakan bahwa setiap karyawan yang bekerja selalu diingatkan untuk bersikap disiplin. ND selalu mengingatkan pentingnya berperilaku disiplin ketika ada yang lupa. Salah satu contohnya adalah sikap disiplin yang akhirnya menjadi sebuah kebiasaan bagi para karyawan yang bekerja di Samakta Guest House adalah jam istirahat. Ketika para karyawan mendapatkan hak istirahat selama satu jam, maka para karyawan akan mempergunakan itu dengan baik dan tidak akan telat untuk bekerja kembali setelah satu jam beristirahat. Begitu juga saat jam masuk kerja. Karyawan yang tidak menginap atau tinggal di Samakta Guest House adalah mereka yang sudah berkeluarga atau tinggal di sekitaran penginapan tersebut. Karyawan yang tidak tinggal di Samakta Guest House menjadi terlatih dan terbiasa untuk datang sebelum jam kerja dimulai. 
Asumsi lainnya adalah pemikiran bahwa apa yang diyakini seseorang, nilai dan perasaan yang dimiliki seseorang serta penilaian terhadap diri mempengaruhi perilaku orang tersebut (LaRossam da Reitzes, dalam West dan Turner, 2014:77-78). Dalam hal ini, JF dan PL memiliki dedikasi tinggi, kemauan belajar yang luar biasa tinggi dan kemandirian serta ketrampilannya sangat bagus. Nilai yang ada dalam diri mereka inilah yang mempengaruhi perilaku mereka. Menurut ND, tidaklah sulit untuk mengajarkan hal-hal baru pada JF dan PL. JF dan PL banyak belajar dan itu membuat mereka berubah menjadi pribadi baru yang lebih baik. Saat JF dan PL mulai memiliki rasa percaya diri yang tinggi dan percaya bahwa mereka tidak berbeda dengan orang lainnya serta punya ketrampilan yang baik, JF dan PL menjadi rajin, produktif dan aktif dalam bekerja.

Menurut Hecht (Samovar et al., 2013:219), identitas bermula dari pengaruh interaksi melalui pembentukan harapan dan motivasi perilaku. Kita mengalami berbagai proses ketika berinteraksi dengan orang lain. Bagaimana interaksi tersebut dapat membuat kita sesuai dan nyaman dalam pembentukan identitas. Menurut JF dan PL, mereka merasakan adanya perbedaan antara sebelum dan setelah mereka bekerja di Samakta Guest House. Baik JF maupun PL merasakan kenyamanan setelah menjadi bagian dari Samakta Guest House. JF dan PL bisa mengembangkan diri mereka dengan baik dan mereka merasa bahwa mereka adalah bagian (dan bahkan keluarga) dari Samakta Guest House. Berdasarkan wawancara yang dilakukan dengan ND, perbedaan pada diri JF dan PL juga dirasakan olehnya. Ada perubahan dari awal JF dan PL mulai bergabung dan bekerja di Samakta Guest House hingga saat ini. JF dan PL menjadi sosok yang mandiri dan dapat berbaur dengan orang lain. Kreativitas dan kerajinan yang ditunjukkan oleh JF dan PL dapat dilihat dari saat JF dan PL bekerja dan menghasilkan berbagai produk (seperti souvenir dari tanah liat) untuk dijual dan dipamerkan di Samakta Guest House itu sendiri. Menurut ND, apa yang diajarkan oleh ND dan DD juga diikuti oleh JF dan PL dengan baik. Menurut ND, JF dan PL mudah mengingat dan beradaptasi dengan cepat terhadap hal baru dan mereka selalu menunjukkan semangat untuk terus belajar.

\section{Simpulan}

Berdasarkan hasil analisis, maka terdapat dua kesimpulan dalam penelitian ini. Pertama, dapat disimpulkan bahwa budaya organisasi yang ada di Samakta Guest House adalah budaya kekeluargaan, budaya berorientasi manusia dan inovasi, serta pengambilan resiko. Budaya organisasi yang ditanamkan kepada karyawan di Samakta Guest House adalah budaya kekeluargaan yang dapat dilihat melalui kebersamaan dan memperlakukan sesama tanpa membeda-bedakan. Inovasi dan pengambilan resiko dapat dilihat dari adanya motivasi yang kuat dalam diri JF dan DD yang membuat mereka sering memunculkan ide-ide unik yang akhirnya direalisasikan.

Kesimpulan kedua adalah terjadi pergeseran budaya dalam diri JF dan PL yang membentuk identitas baru dalam diri JF dan PL melalui proses interaksi dengan orang lain yang ada di Samakta Guest Gouse. Sebagai penyandang Tuli, JF dan PL memiliki budaya 
dan identitas pada dirinya masing-masing. Akan tetapi, budaya dan identitas yang ada pada diri JF dan PL tersebut mengalami pergeseran saat keduanya bekerja di Samakta Guest House. Bertemu dengan berbagai jenis orang dan juga mengalami berbagai interaksi membentuk identitas baru pada diri JF dan PL. JF dan PL beradaptasi dengan budaya yang baru ditemui atau dialaminya saat bekerja di Samakta Guest House. JF dan PL melakukan adaptasi melalui proses interaksi yang dilakukan dengan atasan, rekan-rekan kerja, dan bahkan pelanggan. Proses interaksi yang sangat berperan penting dalam pembentukan identitas baru tersebut merupakan interaksi yang dilakukan dengan atasan dan rekan-rekan sesama karyawan.

Dengan adanya keterbatasan pada penelitian ini di mana pengumpulan data lebih banyak dilakukan secara tertulis, maka disarankan bagi peneliti selanjutnya dapat melakukan penelitian serupa dengan menggunakan wawancara lisan atau dapat juga melakukan penelitian dengan menggunakan sudut pandang yang berbeda. Hal ini dikarenakan budaya selalu mengalami perubahan. Kelanjutan dari penelitian seperti ini dapat memberikan kekayaan dan keragaman pada studi komunikasi antarbudaya. Substansi penelitian ini memberikan rekomendasi kepada organisasi, khususnya pengelola Samakta Guest House untuk selalu menanamkan budaya organisasi peduli difabel. Pembentukan identitas dapat terjadi karena pengenalan dan pemahaman mengenai budaya organisasi peduli difabel yang baik dalam diri karyawan.

\section{Daftar Pustaka}

Adyapradana, G. (2018). Identitas dan Pembentukan Stereotip Pemain Indonesia Dalam Online Game. Jurnal Komunikasi Indonesia, 4(2), 1-9. https:// doi.org/10.7454/jki.v4i2.8884

Croucher, Stephen M., \& Cronn-Mills, Daniel. (2015). Understanding Communication Research Methods. New York: Routledge.

DeVito, Joseph A. (2016). The Interpersonal Communication Book, 14th Edition. Inggris: Person Education Limited.

Dewi, P. A. R. (2017). Konstruksi Identitas Kedaerahan oleh Media Massa Lokal. Jurnal ASPIKOM, 1(2), 149. https://doi. org/10.24329/aspikom.v1i2.14

Dewi, Y. C., Widyowati, W., Manajemen, P., Fakultas, K., Komunikasi, I., \& Padjadjaran, U. (2017). The Formation Process Of Adolescents Cultural Identity From Family By Maritalwith Different Culture. 1(2).

International Labour Organization. (2013). Inklusi Penyandang Disabilitas di Indonesia http://www.ilo.org/wcmsp5/ groups/public/---asia/---ro-bangkok/--ilo-jakarta/documents/publication/ wcms_233426.pdf diakses pada 18 Mei 2018 .

Jhalugilang, P., Ilmu, F., Dan, S., Politik, I., Studi, P., Sarjana, P., ... Indonesia, U. (2012). Universitas Indonesia Makna Identitas Fans Klub Sepak Bola (Studi Kasus : Juventus Club Indonesia) Tesis.

Nassaji, H. (2015). Qualitative and descriptive research: Data type versus data analysis. Language Teaching Research, 19(2), 129-132. https://doi. org/10.1177/1362168815572747

Robbins, Stephen P., \& Coulter, Mary. (2012). Management, 11th Edition. New Jersey: Pearson. 
Samakta, Kubca. (2012, April 10). KUBCA SAMAKTA (Kelompok Usaha Bersama Penyandang Cacat Jasa Mitra Karya Utama) http://ksamakta.blogspot. co.id/2012/04/kubca-samaktakelompok-usaha-bersama.html, diakses pada 16 April 2018.

Samovar, Larry A., Porter, Richard E., \& McDaniel, Edwin R. (2013). Communication between Cultures,
8E, International Edition. Boston: Wadsworth.

Setyaningsih, R. (2016). Pengembangan Kemandirian Bagi Kaum Difabel. 31(1), 42-52.

West, Richard \& Turner, Lynn H. (2014). Introducing Communication Theory: Analysis and Application, 5th Edition, International Edition. New York: McGraw-Hill Education. 